\title{
Testing Single and Combinations of Amendments for Stabilization of Metals in Contrasting Extremely Contaminated Soils
}

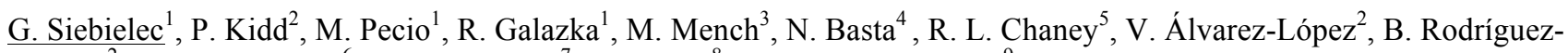

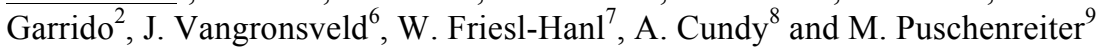

\author{
${ }^{1}$ Institute of Soil Science and Plant Cultivation, Dept. Soil Science Erosion and Land Protection, Czartoryskich 8 , \\ Pulawy, 24-100, Poland,gs@iung.pulawy.pl \\ ${ }^{2}$ Instituto de Investigaciones Agrobiológicas de Galicia (IIAG), CSIC, Avda. de Vigo s/n, Santiago de Compostela \\ 15780, Spain \\ ${ }^{3}$ UMR BIOGECO INRA 1202, Ecology of Communities, University of Bordeaux 1, Bât B2, RdC Est, avenue des \\ Facultés, F-33405 Talence, France, and INRA, 69 route d'Arcachon, 33610 Cestas, France \\ ${ }^{4}$ Ohio State University, Columbus, OH 43210 \\ ${ }^{5}$ USDA-ARS, EMBUL, Beltsville, MD 20705 USA \\ ${ }^{6}$ Universiteit Hasselt, Environmental Biology, Agoralaan, Gebouw. D, BE-3590 Diepenbeek, Belgium \\ ${ }^{7}$ AIT Austrian Institute of Technology GmbH, Health and Environment Department, Konrad-Lorenz-Straße 24, A-3420 \\ Tulln, Austria \\ ${ }^{8}$ University of Brighton, Environment and Technology, BN24AT, United Kingdom \\ ${ }^{9}$ BOKU, University of Natural Resources and Applied Life Sciences, Dept. Forest and Soil Sciences, Rhizosphere \\ Ecology and Biogeochemistry Group, Peter Jordan Strasse 82, A-1190 Vienna, Austria
}

\begin{abstract}
Metals can be stabilized by soil amendments that increase metals adsorption or alter their chemical forms. Such treatments may limit the risk related to the contamination through reduction of metal transfer to the food chain (reduction of metal uptake by plants and its availability to soil organisms) and metals migration within the environment. There is a need for experiments comparing various soil amendments available at reasonable amounts under similar environmental conditions. The other question is whether all components of soil environment or soil functions are similarly protected after remediation treatment. We conducted a series of pot studies to test some traditional and novel amendments and their combinations. The treatments were tested for several highly $\mathrm{Zn} / \mathrm{Cd} / \mathrm{Pb}$ contaminated soils. Among traditional amendments composts were the most effective - they ensured plant growth, increased soil microbial activity, reduced $\mathrm{Cd}$ in earthworms, reduced $\mathrm{Pb}$ bioaccessibility and increased share of unavailable forms of $\mathrm{Cd}$ and $\mathrm{Pb}$.
\end{abstract}

Key words: phytostabilisation, soil amendments, trace elements, contaminated soil, bioavailability

\section{Introduction}

There is a need to reduce the negative impacts of trace element polluted soils on human health and the environment. Metals can be stabilized by amendments increasing metal adsorption or altering their chemical form (Basta et al., 2005). Few experiments compare different in situ remediation treatments under similar environmental conditions, or consider whether or not all soil components or properties (microbes, soil fauna, plants, soil retention function, stability of colloids, etc.) are similarly protected.
The objective of our studies was to compare effectiveness of various materials in stabilizing metals in highly $\mathrm{Zn} / \mathrm{Pb} / \mathrm{Cd}$ contaminated soils. The other goal was to test interaction between metals solubility and behaviour of plants, soil organisms and microbial activity in the treated soils.

\section{Materials and Methods}

Within national project funded by Polish Ministry of Science (project number 2 P04G 06130) we tested a range of traditional soil amendments. The tested treatments were: NPK, compost GWDA (rate $10 \% \mathrm{w} / \mathrm{w})$, 
compost Zabrze (10\%), biosolids (10\%), Ca-phosphate $\left(\mathrm{CaHPO}_{4}\right.$ reagent grade) $(\mathrm{P}=2 \%), \mathrm{Fe}$ oxide $\left(\mathrm{Fe}(\mathrm{OH})_{3}\right.$ reagent grade) $(\mathrm{Fe}=2 \%)$, Rock waste $(10 \%)$, Bentonite $(5 \%)$, Limestone (Ca-carbonate reagent grade) $(10 \%)$. Composts represented different composting technologies and substrates (biosolids, municipal green wastes or mixed biodegradable wastes). The treatments were tested for 3 highly $\mathrm{Zn} / \mathrm{Cd} / \mathrm{Pb}$ contaminated soils with various origin of contamination including "natural" geological contamination (high metal content in a parent rock) - soil G, long-term contamination by smelter dusts - soil LS and short-term contamination by smelter dusts - soil SS. Soil $\mathrm{pH}$ ranged between 7.1 and 7.6 while total $\mathrm{Zn}$ content between 3900 and $18800 \mathrm{mg} \mathrm{kg}^{-1}$ ).

The effects of soil amendments were assessed based on responses of various parameters. Metals solubility was measured by neutral salt extractions. Different plants were grown in pots (mustard, oat) - their yield was recorded and chemical composition analyzed. Plant availability of metals was tested in a dynamic manner directly after the treatment and in a longer perspective.

Metal absorption by earthworms was measured. Potential direct effects on humans were measured by in vitro gastrointestinal test. We also measured metals leaching and selected soil physical parameters that might be significantly changed after amendments and water movement in a soil profile.

Within the EU FP7 Greenland project (266124) we compared the impact of novel soil amendments and their combinations with traditional materials on metal solubility and the response of plants, soil organisms and microbial activity.

Two greenhouse pot experiments were established: soil A, less toxic agricultural soil contaminated through long-term $\mathrm{Zn} / \mathrm{Pb}$ smelter emissions in Poland $(\mathrm{pH} 7.0$, total $\mathrm{Zn}, \mathrm{Pb}$ and $\mathrm{Cd}$ : 2670, 690 and $30 \mathrm{mg} \mathrm{kg}^{-1}$, respectively); soil $\mathrm{B}$, toxic soil contaminated 20 years ago through smelter dust spill in Poland $(\mathrm{pH} 6.8$, total $\mathrm{Zn}, \mathrm{Pb}$ and $\mathrm{Cd}$ : 4070, 1770 and $27 \mathrm{mg} \mathrm{kg}^{-1}$, respectively, large pool of soluble $\mathrm{Zn}$ and $\mathrm{Cd}$ ); and soil $\mathrm{C}$, toxic $\mathrm{Cu}-$ contaminated mine spoils in Spain (very acidic - $\mathrm{pH}$ 3.6, total $\mathrm{Cu}$ up to $1200 \mathrm{mg} / \mathrm{kg}$ ).

The following treatments were tested as single amendments and in different combinations in both planted and unplanted soils: compost, drinking water residue, iron grit, Ca-phosphate, LD slag, Thomas basic slag, gravel sludge, siderite, Fe nano-sorbent, and cyclonic ash. Reagent grade $\mathrm{CaCO}_{3}$ was added to soils if needed in order to establish soil $\mathrm{pH}$ at comparable level in all treatments. Amendment rates were based on prior batch tests. The more toxic soils (B and C) were planted with grasses whereas soil A was seeded with lettuce. The experiment was run for 1-year, and plants were periodically harvested, the yields recorded and samples analyzed for metal content. Soil samples were collected for analysis of metal extractability and bioaccessibility, soil $\mathrm{pH}$, electric conductivity and enzymatic activity. Soil pore waters were collected peridocially to determine trace element concentrations. A separate test was performed with the treated soils to study amendment effects on earthworm behaviour and metal accumulation.

The presentation will summarize the effects of the broad range of the soil amendments with an emphasis given to their benefits and weaknesses.

\section{Results and Discussion}

This paper presents the results of the first series of experiments focused on traditional amendments. The outputs of the second series aimed at assessment of novel treatments are under preparation and they wil be available for the conference presentation.

Generally organic treatments were the most effective in increasing the plant yield and reducing phytotoxicity symptoms. However there were differences between compost and biosolids effects. Biosolids caused dynamic changes of $\mathrm{pH}$ and metals mobility and should be applied with lime.

Composts were the most effective among tested remediation treatments - they enabled plant growth, increased soil microbial activity, reduced $\mathrm{Cd}$ in earthworms (Table 1) and reduced $\mathrm{Pb}$ in vitro bioaccessibility. Phosphates reduced $\mathrm{Pb}$ bioaccessibility and concentration in leachates. Fe oxides reduced metals solubility and content in plants as well as $\mathrm{Cd}$ accumulation in earthworms. On the other hand $\mathrm{Fe}$ oxides enhanced macro- and microelement deficiences.

Table 1. The effect of the treatments on metal content in earthworm tissues

\begin{tabular}{lccc}
\hline & $\mathrm{Cd}$ & $\mathrm{Zn}$ & $\mathrm{Pb}$ \\
\hline Initial & 0.41 & 92.1 & 0.5 \\
\hline Clean reference soil & 10.1 & 114 & 10.5 \\
& & & \\
\hline Untreated soil LS & $112.5 \mathrm{a}$ & $290 \mathrm{a}$ & $409 \mathrm{a}$ \\
Soil LS + GWDA & $50.8 \mathrm{c}$ & $271 \mathrm{a}$ & $312 \mathrm{ab}$ \\
Soil LS + Zabrze & $48.3 \mathrm{c}$ & $368 \mathrm{a}$ & $336 \mathrm{ab}$ \\
Soil LS + P & $66.3 \mathrm{bc}$ & $269 \mathrm{a}$ & $352 \mathrm{ab}$ \\
Soil LS + Fe & $70.5 \mathrm{bc}$ & $359 \mathrm{a}$ & $226 \mathrm{~b}$ \\
Soil LS + Rock & $90.4 \mathrm{ab}$ & $247 \mathrm{a}$ & $382 \mathrm{ab}$ \\
Soil LS + Benton. & $86.0 \mathrm{ab}$ & $275 \mathrm{a}$ & $333 \mathrm{ab}$ \\
Soil LS + Lime & $94.3 \mathrm{ab}$ & $271 \mathrm{a}$ & $332 \mathrm{ab}$ \\
\hline \multicolumn{4}{c}{$*$ different letters - significant difference at $\mathrm{p}<0.05$}
\end{tabular}

\section{Conclusions}

Composts are effective as a single treatment. Phosphates, iron oxides and lime might be valuable supplements for the composts. It is also purposeful to select high $\mathrm{P}, \mathrm{Fe}$ and Ca-carbonate composts for remediation (Tailor Made composts). Treatments positively affecting metals solubility, plant growth, metals bioavailability, metals leaching, microbial activity, plant metals content were defined. None of tested treatments protected earthworms, however some of them reduced $\mathrm{Cd}$ and $\mathrm{Pb}$ accumulation in earthworm tissues. 


\section{Acknowledgments}

The presented experiments were conducted within the following projects::

- National project funded by Polish Ministry of Science and Higher Education, project number 2 P04G 06130
- 7FP GREENLAND project, project number 266124.

\section{References}

Basta NT, Ryan JA, Chaney RL. Trace element chemistry in residual-treated soil: Key concepts and metal bioavailability. J. Environ. Qual. 2005; 349-63. 